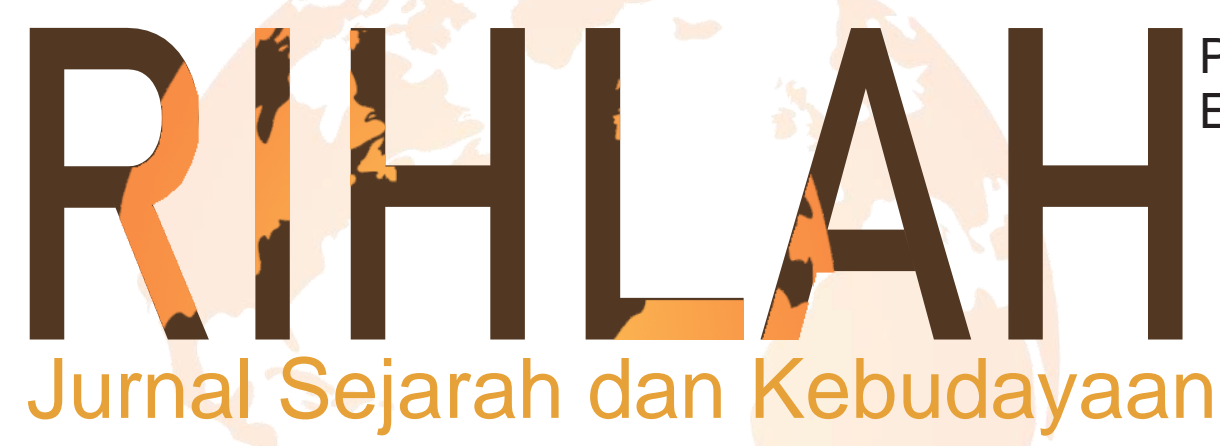

P-ISSN: 2339-0921

E-ISSN: 2580-5762

Pengaruh Bugis di Tanah Melayu dalam Perspektif Sejarah Sosial Politik Saepuddin

Akulturasi Budaya: Adat Pernikahan di Kelurahan Cikoro Kecamatan Tompobulu Kabupaten Gowa St. Hajar, M. Dahlan M, Syamzan Syukur

Corry Van Stenus, Perempuan dalam Perjuangan Abdul Qahhar Mudzakkar (1950-1965) Nurul Azizah

Sejarah dan Penyebaran Islam di Asia dan Afrika Herman Wicaksono

Sarekat Islam Penggagas Nasionalisme di Indonesia Soraya Rasyid, Annisa Tamara

Bergerak dengan Dua Sayap: Fenomena Gerakan Dakwah dan Politik Hizbut Tahrir di Indonesia Pasca Reformasi Aksa 


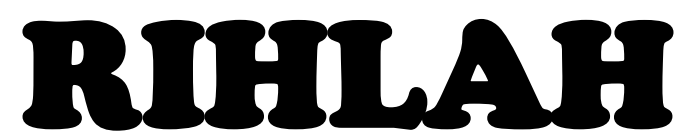

Jurnal Sejarah dan Kebudayaan

\begin{tabular}{|c|c|}
\hline Editor in Chief & : Dr. Rahmat, M.Pd. \\
\hline Managing Editor & : Mastanning, S.Hum, M.Hum. \\
\hline Editorial Board & $\begin{array}{l}\text { : Nur Ahsan Syukur, S.Ag, M.Si. } \\
\text { : Chaerul Munzir, S.Hum, M.Hum. } \\
\text { : Lydia Megawati, S.Hum, M.Hum. } \\
\text { : Muhammad Husni, S.Hum, M.Hum. } \\
\text { : Zaenal Abidin, S.S., M.H.I. } \\
\text { : Chusnul Chatimah Asmad, S.IP, M.M. } \\
\text { : Muhammad Arif, S.Hum, M.Hum. } \\
\text { : Nurhidayat, S.Hum, M.Hum. }\end{array}$ \\
\hline Desain Grafis & : Nur Arifin, S.IP. \\
\hline Secretariat & : Safaruddin, S.Hum. \\
\hline Reviewers & $\begin{array}{l}\text { : Prof. Dr. H. Abd. Rahim Yunus, M.A. } \\
\text { : Prof. Dr. H. Ahmad M. Sewang, M.Ag. } \\
\text { : Dr. Hj Syamzan Syukur, M.Ag. } \\
\text { : Dr. Nasruddin Ibrahim. } \\
\text { : Dr. Abd. Rahman Hamid. } \\
\text { : St. Junaeda, M.Hum. } \\
\text { : Dr. Rahmawati, MA. } \\
\text { : Dr. Nurhayati Syairuddin, M.Hum }\end{array}$ \\
\hline
\end{tabular}

Alamat Redaksi dan Tata Usaha : Jurusan Sejarah dan Kebudayaan Islam Fakultas Adab dan Humaniora UIN Alauddin Makassar, Jln. Sultan Alauddin No. 36 Samata Gowa Tlp. 0411-841879 Fax.0411-822140 (Kampus II) E.Mail. rihlah@uin-alauddin.ac.id

Jurnal Rihlah terbit dua kali dalam setahun, bulan Juni dan bulan Desember berisi kajian tentang Sejarah dan Kebudayaan, baik dari hasil penelitian maupun tulisan ilmiah lainnya.

Penyunting menerima tulisan yang belum pernah diterbitkan oleh media cetak lain. Naskah diketik spasi $1 \mathrm{~cm}$ pada kertas berukuran A4 dengan tulisan berkisar 12-23 halaman. Naskah yang masuk dievaluasi oleh Dewan Penyunting. Penyunting dapat melakukan perubahan pada tulisan yang dimuat untuk keseraganan format, tanpa mengubah maksud dan konten tulisan. 
Saepuddin $01-17$

Pengaruh Bugis di Tanah Melayu dalam Perspektif Sejarah Sosial Politik

St. Hajar, M. Dahlan M, Syamzan Syukur

Akulturasi Budaya: Adat Pernikahan di

Kelurahan Cikoro Kecamatan Tompobulu

Kabupaten Gowa

Nurul Azizah.

Corry Van Stenus, Perempuan dalam Perjuangan

Abdul Qahhar Mudzakkar (1950-1965)

Herman Wicaksono.

Sejarah dan Penyebaran Islam di Asia dan Afrika

Soraya Rasyid, Annisa Tamara

$66-84$

Sarekat Islam Penggagas Nasionalisme di Indonesia

Aksa

Bergerak dengan Dua Sayap: Fenomena Gerakan Dakwah

dan Politik Hizbut Tahrir di Indonesia Pasca Reformasi 


\title{
Bergerak dengan Dua Sayap: Fenomena Gerakan Dakwah dan Politik Hizbut Tahrir di Indonesia Pasca Reformasi
}

\author{
Akssa \\ Universitas Islam Negeri Alauddin Makassar \\ aksa131288@gmail.com
}

\section{Abstract}

This paper explains about the phenomenon of HTI politics and its da'wah movement after reformation. The main problems answered in this paper are: what are the activities of da'wah and political movements of HT in Indonesia?, And how is the form of HTI da'wah through social media and publications? The writing method used the historical writing method which included four stages (heuristics, literary criticism, interpretation and historiography). The results showed that da'wah and the politics of Hizbut-Tahrir in Indonesia is a mainstream phenomenon from a preaching model and politics in general. HTI has played two orientation movements (preaching and politics) in establishing its influence in Indonesia. The da'wah and political movements appeared ambiguous. In terms of da'wah, the activities were more focused on proposing a single ideology and anti-democracy. But at the same time, taking cover themselves behind the armpit of the country which adheres to the democratic system and the ideology of Pancasila. While in the political perspective, its movement was seen as a half-hearted political movement, claiming to be a political movement, but it did not have a political party and was not involved in the electoral contestation. HTI da'wah was increasingly effective by utilizing media and publications (books, magazines, tabloids, and bulletins). The use of social media as a concrete approach has made social media as a mean of preaching.

Keywords: Dakwah; Politic,; Hizbut Tahrir; Indonesian.

Tulisan ini menjelaskan tentang fenomena gerakan dakwah dan politik HTI pasca reformasi. Masalah pokok yang dijawab dalam tulisan ini yaitu: bagaimana aktivitas dakwah dan gerakan politik HT di Indonesia?, dan bagaimana bentuk dakwah HTI melalui sosial media dan publikasi?. Metode penulisan mengikuti metode penulisan sejarah yang meliputi empat tahapan (heuristik, kritik sumber, interpretasi dan historiografi). Hasilnya menunjukan bahwa dakwah dan politik Hizbut Tahrir di Indonesia adalah sebuah fenomena mainstream dari model dakwah dan politik umumnya. HTI telah memainkan dua orientasi gerakan (dakwah 
dan politik) dalam menancapkan pengaruhnya di Indonesia. Gerakan dakwah dan politiknya terlihat ambiguitas. Dari segi dakwah, aktivitasnya lebih terfokus pada pengusulan ideologi tunggal dan anti demokrasi.Tetapi pada saat bersamaan, berlindung diri di balik negara Indonesia yang menganut sistem demokrasi dan berideologi Pancasila.Sementara dari segi politik, gerakannya terkesan sebagai gerakan politik setengah hati, mengklaim dirinya sebagaigerakan politik, tetapitidak memiliki partai politik dan tidak terlibat dalam kontestasi pemilu. Dakwah HTI semakin efektif dengan memanfaatkan media dan publikasi (buku, majalah, tabloid, dan bulletin).Pemanfaatan sosial media sebagai langkah kongkrit menjadikan sosial media sebagai sarana dakwah.

Kata Kunci: Dakwah; Politik; Hizbut Tahrir; Indonesia.

\section{Pendahuluan}

Fenomena gerakan keislaman di Nusantara nampaknya sudah ada sejak masa kolonial Belanda. Lahirnya gerakan keagamaan (khususnya agama Islam) seperti Muhammadiyah, Nahdlatul Ulama (NU), Al-Irsyad Al-Islamiyyah (Jam'iyat al-Islah wal Irsyad al-Islamiyyah), Persatuan Islam (Persis), dan Jamiah al-Islamiyah masa kolonial telah berkontribusi dalam menanamkan dan mengembangkan nilainilai keislaman masyarakat. Selain itu, Kehadiran ormas Islam periode awal sekaligus membentengi gerakan para Misionaris dan Zending dalam menyampaikan berita gembira (penginjilan) di Indonesia.Pasca Indonesia merdeka tahun 1945, gerakan keislaman mengalami perubahan dan perkembangan orientasi. Muhammadiyah dan Nahdlatul Ulama (NU) bermetamorfosis menjadi gerakan populis tanpa mengabaikan gerakan sosial keagamaannya. Keduanya membangun ikatan kultural dalam memperkuat identitas politik Islam. Majelis Syuro Muslimin Indonesia (Masyumi), menjadi representasi kekuatan politik Islam sekaligus sebagai model kesadaran dalam Islam politik saat itu.

Kehadiran Islam sebagai kekuatan politik era Orde Lama menimbulkan kewaspadaan bagi keberlangsungan penguasa era Orde Baru. Oleh karenanya, sebagai salah satu langkah dalam membatasi kekuatan Islam politik (termasuk kekuatan eks Masyumi), rezim Orde Baru di bawah kendali Jenderal Soeharto mulai mengikis gerakan Islam satu persatu.Kelompok Islam politik yang memiliki komitmen perjuangan mengubah bentuk negara menjadi negara Islam atau setidaknya yang memperjuangkan formalisasi syariat Islam di Indonesia, oleh rezim Orde Baru melabelinya sebagai kelompok ekstrem kanan.

Runtuhnya rezim Orde baru tahun 1998, menjadi angin segar bagi gerakangerakan Islam yang sulit mengekspresikan dirinya selama Jenderal Soeharto berkuasa. Beragam kelompok gerakan (keagamaan Islam) maupun yang 
mengatasnamakan Islam mulai bermunculan mewarnai pentas keislaman di Indonesia. Gerakan dan kelompok tersebut memiliki ragam bentuk, ada yang tampil dalam bentuk sedehana, terbatas dan ekslusif seperti komunitas An-Nadzir, Al-Qiyadah Al-Islamiyah dan Gerakan Fajar Nusantara (Gafatar). Ada yang tampil dalam bentuk ekspresif seperti Forum Umat Islam (FUI) dan Front Pembela Islam (FPI).Ada pula muncul dalam bentuk yang radikal seperti Majelis Mujahiddin Indonesia (MMI), Jamaah Islamiyah (JI) dan kelompok Salafi Jihadis (SJ).

Erareformasi, bagi kelompok gerakan atau ormas-ormas Islam adalah era keterbukaan untuk mengekspresikan kebebasan berpendapat dan beragamayang telah lama terkungkung dalam era kegelapan (era Orde baru).Salah satu organisasi yang merasakan kebebasan berorganisasi awal reformasi adalah Hizbut Tahrir Indonesia (selanjutnya disingkat HTI).Organisasi yang berlambangkan kalimat tauhid ini tampil di ruang publik kali pertama pada tahun 2000 di Istora Senayan, Jakarta.

Aktivitas dan gerakan yang dimainkan oleh HTI dalam dakwah dan Politik menjadi sebuah fenomena mainstream dari model dakwah dan politik umumnya yang berlaku di Indonesia. HTI telah memainkan dua model gerakan yang dianggap mampu menancapkan pengaruhnya di Indonesia, yaitu gerakan dakwah dan politik sebagai gerakan dengan dua sayap.Sungguh sebuah gerakan yang terlihat ambigu. Pasalnya, jika ditinjau dari sisi gerakan dakwah, aktivitas HTI sangat kental dengan narasi-narasi politik dan berorientasi ideologis. Sementara dari segi politik, terkesan sebagai gerakan setengah hati, yaitu berpolitik tanpa partai.Karenanya, aktivitas politik HTImenjadi semakin serampangan.Sebab partai politik dalam istilah dan terminologi umum diterjemahkan berdasarkan pengertian sesuai seleranya.

Berangkat dari titik awal masalah di atas, maka tulisan ini menjelaskan seputar fenomena gerakan dakwah dan politik Hizbut Tahrir pasca reformasi yang dilabeli dengan judul "Bergerak dengan Dua Sayap: Fenomena Dakwah dan Politik Hizbut Tahrir di Indonesia Pasca Reformasi” Sub pokok masalah sebagai turunan dari masalah pokok yang dijelaskan dalam tulisan ini ada dua (2) yaitu: bagimana aktivitas dakwah dan gerakan politik HT di Indonesia?, dan bagimana bentuk dakwah HTI melalui dakwah dan publikasi?.

\section{Gerakan Dakwah dan Politik HTI Pasca Reformasi}

Aktivitas dakwah yang dimainkan oleh HTIpasca reformasisejatinya adalah kegiatan yang bersifat politik.Dalam sebuah bukuberjudul mengenal HT dan strategi dakwah HT mengemukakan bahwa seluruh aktifitas dakwah yang dilakukannya berorientasi politik.HTItetapForum Umat Islam (FUI) 
Bergerak dengan Dua Sayap: Fenomena Gerakan Dakwah dan

Politik Hizbut Tahrir di Indonesia Pasca Reformasi

Aksa

memprioritaskan kepentingan masyarakat dan mencari solusi terbaik sesuai dengan syari'at Islam. Bagi HTI, berpolitik merupakan sarana terbaik dalam melayani kepentingan ummat dan menjalankannya harus sesuai dengan syariat Islam. Kegiatan-kegiatan yang sifatnya bernuansa politik ini telah nampak dalam usahanya membimbing dan mengedukasi ummat dengan model tsaqafah (pembinaan) slam.

HTI berusaha membebaskan ummat dari berbagai pemikiran dan pandangan yang dapat merusak akidah Islam. Kegiatannyayang bernuansa politik dapat ditelusuri dalam narasi-narasi ideologis yang diwacanakan oleh shababshababdemi menanamkan pengaruhnyadi Indonesia. Lebih lanjut, perjuangan politiknya semata-mata demi menantang penguasa yang dinilainya dzolim, yang merasa nyaman dalam singgasana kekuasaan tetapi abai terhadap penderitaan ummat Islam. Karenanya, HT sering melancarkan kritikan-kritikanya terhadap pemerintah dengan cara mengontrol, mengoreksi, mengkritik para penguasa yang tidak melaksanakan tugas dan kewajibannya. Ini adalah langkah konkrit yang mereka lakukan jika penguasa menafikan kepentingan masyarakat (umat Islam) dan tidak berpedoman dengan syariat atau hokum Islam.

Konsistensi gerakan dakwah dan politik HTI di luar mainstream umum terlihat dalam pemikirannya yang menentang ide-ide dari Barat Sistem demokrasi dan seperangkat aturan yang datang dari barat mereka nilai sebagai sistem kufur dan aturan-aturan yang salah yang lahir dari pemahaman yang keliru.Setelah mereka ungkapkan kekeliruan yang dianut oleh umat, kemudian mereka menjelaskan kerusakan dengan cara meluruskan dengan menjelaskan solusi dari kekeliruan yang dimaksud. Apabila dilihat dari orientasi gerakannya, HTI dapat dikategorikan sebagai organisasi yang mempunyai orientasi dakwah dan politik, terlepas dari kategori ini masih memunculkan perdebatan yang panjang. Mengingat HTI telah menyebut dirinya sebagai gerakan (partai) politik, tetapi tidak pernah/ikut terlibat dalam kontestasi pemilihan umum (pemilu) sebagaimana yangpernah dilakukan oleh partai-partai politik lainnya.

Organisasi yang memiliki dua orientasi inilah oleh Shobron sebagai organisasi yang bergerak dengan dua sayap, yakni sayap dakwah dan sayap politik.Orientasi dua sayap tersebut dapat dimaknai sebagai dualitas yang saling mendukung dalam perjuangannya.Dakwah demi politik, dan politik sebagai payung dalam berdakwah.Dakwah demi politik bermakna bahwa semua aktivitas dakwah memiliki kepentingan politik yang dapat dijadikan landasandalam meraih kekuasaan. Sementara politik sebagai payung dalam berdakwah bermakna kekuasaan yang telah diraih dari intrik politik dapat melegitimasi kepentingan dalam berdakwah. 
Gerakan Hizbut Tahrir dengan dua sayap orientasinya mempunyai kelebihan dan kekurangannya.Kelebihan (nilai positif) orientasi ini menurut Shobronsebagai representasi kesempurnaan ajaran Islam yang mengatur kehidupan umat Islam termasuk dalam hidup berbangsa dan bernegara.Dakwah dan politik adalah dua hal yang bersatu tidak bisa dipisahkan dalam aktivitasnya.Kedua orientasi gerakan ini bagaikan dua sisi dalam kepingan mata uang yang tidak bisa dipisahkan.Karenanya, dakwah HTI memerlukan strategi, pola, dan metode demi kekuasaan.Sedangkan kekurangan (nilai negatif) dari orientasi dua sayap tersebut dapat mereduksi kesucian dan kesempunaan atas nilai-nilai Islam sendiri. Dengan kata lain, bahwa kekuasaan seakan-akan menjadi tujuan hidup ketika kita berislam. Hasrat berkuasa yang dilakukan dengan menghalalkan segala cara tentu mengeliminir nilai-nilai, etika dan moralitas yang dianutnya. Termasuk diantaranya adalah praktek money politic dengan caramembeli suara secara langsung maupun melalui "broker politik" dengan nilai rupiah tertentu.

Kegiatan dakwah Hizbut Tahrir pasca reformasidi Indonesia secara umumtermasuk dalam kategori kegiatan yang berorientasi politik, sehingga penulis menilai bahwa dakwah dan politik adalah bentuk aktivitas yang dilakukan oleh aktivis HT di Indonesia dalam dua sayap. Istilah ini bukan istilah yang digunakan atau yang keluar dari ucapan aktivis HTI, namun istilah ini adalah istilah yang digunakan oleh penulis untuk menjustifikasi kegiatan mereka. Penggunaan istilah ini bukan tanpa sebab, karena berdasarkan fakta dan data yang telah ditemukan di lapangan membenarkan tentang adanya aktivitas dakwah dan politik mereka selama berkiprah di

Indonesia.

\section{Aktivitas Dakwah Hizbut Tahrir di Indonesia}

HTI mengembangkan aktivitas dakwah Islam dengan harapan agar aqidah Islam menjadi dasar dalam bernegara dan berkonstitusi yangmengatur kehidupan umat manusia di Indonesia dan di dunia secara umumnya. Karenanya, aqidah Islamala HT adalah kaidahbagi pemikiran dan politik yang bermuara pada aturan yang dapat memecahkan berbagai problem kehidupan umat manusia. Sebagai langkah untuk merealisasikan dakwahnya, maka banyak hal yang dilakukan oleh Hizbut Tahrir diantaranya yaitu perang pemikiran. Mereka melakukan perang pemikiran dengan cara membongkar kebijakankebijakan pemerintah yang di anggap menindas dan menghianati rakyatnya.Selain itu, mereka juga membongkar agenda-agenda Barat yang masuk ke negara Indonesia. 
Menurut Didi Haryono, perang pemikiran ini dilakukan dalam rangka menyadarkan umat bahwa sesungguhnya bangsa ini dalam kondisi yang terjajah, hanya sajanegara tidak terjajah secara fisik tetapi terjajah secara secara psikis dan pemikiran. Sampai sekarang, negara-negara besar masuk dan mengeksploitasi kekayaan alam di negara Indonesia atas nama investasi dan sejenisnya. Negara Indonesia menjadi tidak berdaya karena terus di jajah. Atas dasar itulah, aktivisaktivis HT berusaha menumbuhkan kesadaran masyarakat dengan pemikiranpemikiran ideologisnya. Dengan kata lain, Islam menjadi satu-satunya solusi untuk menyelesaikan problem yang terjadi di tengah-tengah masyarakat.

Islam sebagai solusi kehidupan dalam pendangan HT adalah Islam yang dipahami dalam kerangka epistemologi yang bersifat ideologis.Paradigma ideologi Islam kaffah dalam terminologi HT yaitu terlaksananya ajaran Islam secara totalitas dalam bingkai Khilafah Islamiyah.Oleh karena itu, aktivis HT berjuang dan bergerak di tengah-tengah masyarakat dan pemerintah menghidupkan kembali model pemerintahan yang mereka nilai cukup ideal yaitu sitem Khilafah Islamiyah. Adapun yang menjadi maksud dan tujuan didirikannya Khilafah Islamiyah oleh HizbutTahrir, sebagian diantarannya adalah: a. Menegakkan dan memurnikan kalimat Tauhid, b. Menyatukan negara-negara mayoritas kaum muslimin dalam satu sistem tunggal dan pemimpin tunggal, c.Ekspansi Islam dengan jalan dakwah dan jihad demi menyelatkan umat Islam dari keterkungkungan, keterbelakangan dan kebodohan, d. Membebaskan negeri-negeri yang dikuasai oleh penguasa yang Dzolim, e. Mengusahakan terpenuhinya kebutuhan pokok dan ketahanan pangan dalam bidang pertanian, f. Pemberdayaan SDM di berbagai bidang, g. menjaga kehormatan kaum muslim.

Usaha mewujudkan maksud dan tujuan didirikannya Khilafah Islamiyah oleh HT, maka perjuangan menurut mereka tidak boleh berhenti. Perjuangan akan terus berlanjut meskipun banyak tantangan yang dihadapinya.Secara umum, aktifitas dakwah HTIdilakukan dalam bentuk Tsaqafah Islam, sebuah model pembinaan Islam ala HTI. Tsaqafah Islamadalah tahap awal penguatan ideologi dalam rangka mencetak kader-kader baru yang siap berdakwah.

Tugas utama Shabab dalam membina kesadaran anggota pemula yaitu membentuk kesadarannya agar berislam secarakaffah dan demi keinginan hidup damai dalam naungan Khilafah Islamiyah.Aktivitas dan gerakan merekasejak tahun 2000 sampai 2010 semakin gencar karena adanya dukungan dari masyarakat yang sebagian berasal dari kalangan ekonomi menengah ke atas.Hizbut Tahrir Indonesia tampil di publik mengampanyekan tentang kewajiban mendirikan dan mengembalikan Khilafah Islamiyahtahun 2000 dalam 
Konferensi Internasional Khilafah Islamiyyah. Secara garis besar, agenda yang diemban oleh HT, yakni mengembalikan kejayaan Islam dengan mendirikan kembali model pemerintahan Islam yang berbentuk Khilafah Islamiyah. Tujuan mengadakan Konferensi Internasionalpertama di Istora Senayan, tentu saja bermaksud mengajak dan mempengaruhi umat Islam kembali hidup dalam negara Islam(Daulah Islam), dengan aturan dan sistem kehidupannya diatur oleh aturan Islam.

\section{Berpolitik Tanpa Partai: Gerakan Setengah Hati dalam Politik Hizbut Tahrir}

Selain berdakwah sebagai langkah memurnikan pemikiran dan ideologinya.HTI juga melakukan berbagai aktivitas dan perjuangan yang mereka sendiri menyebutnya sebagai gerakan politik. Karena itu, Hizbut Tahrir tetap tampil sebagai organisasi yang selalu mengkritisi dan menentang berbagai kebijakan penguasa yang kurang adil. HTI menilai persekongkolan penguasa dengan konglomeratdari negara-negara luar adalah bentuk penjajahan baru yang harus dihentikan.Karena gerakannya demikian, maka seluruh aktivitas HT dinilai sebagai aktivitas bersifat politis.Sebab pengertian politik dalam Islam menurut HTadalah memelihara urusan dan kepentingan umat dalam arti yang sesungguhnya.

Perjuangan politik Hizbut Tahrir yang bertujuan membebaskan umat Islam dari berbagai pemikiranyang salah kemudian mereka berusaha untuk meluruskannya. Dengan demikian, HT menjadi representasi umat Islam dalam perjuangan penerapan Syariat Islam di bawah naungan Khilafah Islamiyah.Sejak berdirinya, HT telahdidesain sebagai organisasi yang bersifat politik. Namun, organisasi politik dalam kacamata HT tentu berbeda dengan pengertian organisasi politik yang dikenal secara umum. Meskipun mengklaim diri sebagai partai politik, HTI tidak terlibat atau mendaftarkan diri secara formal di pemerintahan sebagai partai politik yang ikut dalam kontestasi pemilu. HTI menerjemahkan partai politik sesuai dengan selera atau dalam pengertian tersendiri, yaitu sebagai organisasi yang aktifitasnya bertujuan mengkritisisistem barudan berusaha menggantikan dengan sistem lama. Hal ini dilakukan karena menurut HTI, bahwa situasi perpolitikan saat ini belum mampu memberikan politik yang bermoral.

Pola dan strategi dakwah HTI dalam menyampaikan aspirasi politiknya, dapat dikategorikan sebagai organisasi Islam ekstra-parlementer (bergerak diluar sistem pemerintahan). Pasca reformasi, para Shabab HTI tidak ada satupun yang terlibat atau masuk dalam parlemen sebagai wadah aspirasi kelompoknya.Meskipun demikian, mereka tetap berjuang di tengah-tengah 
masyarakat dalam rangka membina umat Islam.Pada tataran obyek dakwah, HTI tidak pernah membatasi ruang gerakannya.Karenanya berada di luar parlemen memberikan ruang bagi mereka dalam mengekspresikan gerakan.Diantaranya, mereka bisa menyalurkan aspirasinya baik di parlemen maupun ke masyarakat, tanpa dicurigai adanya kepentingan politik. Karena sesuatu yang dilakukan HTI adalah menyampaikan pemikiran yang di perjuangkan oleh HTI sejak berdirinya hingga sekarang. Oleh karena itu, HTI tidak mengikuti rekam jejak partai-partai lain yang ikut andil dalam pemilu dan menjadi anggota legislatif.

Keberadaan organisasi ini sebagai organisasi politik patut untuk dipertanyakan. Mengingat aktivitas dan gerakan mereka tidak memainkan peranperan penting dalam politik praktis, sebagaimana yang dilakukan oleh partai politik modern. Dari hasil pengamatan dan analisis kritis dalam tulisan ini, penulis justru melihat HTI sebagai organisasi yang bergerak dalam bidang sosial dan keagamaan ketimbang disebut sebagai organisasi politik seperti pada awal terbentuknya maupun disebut sebagai partai politik sebagaimana arti dari penamaan gerakan ini (Hizb berarti Partai).

Secara konstitusional, HTI tidak bisadikatakan sebagai sebuah partai politik karena sangat bertentangan dengan UU No. 2 tahun 2008. Dalam UU No. 2 tahun 2008 mengatur tentang pembentukan partai politik, tujuan, fungsi, hak dan kewajiban partai politik.Tujuan pendirian partai politik diantaranya berbunyi: a) Mewujudkan cita-cita nasional bangsa Indonesia sebagaimana yang telah dimaksudkan dalam pembukaan UUD RITahun 1945, b) Menjaga dan memelihara keutuhan NKRI, c) Mengembangkan kehidupan demokrasi berdasarkan Pancasila dengan menjunjung tinggi kedaulatan rakyat dalam NKRI.

Sehingga penulis menilai, bahwa gerakan politik yang dimainkan oleh Hizbut Tahrir tanpa melalui partai politik selama ini adalah gerakan setengah hati dalam politih Hizbut Tahrir di Indonesia. Salah satu alasan penulis untuk mengemukakan demikian, bahwa Hizbut Tahrir tidak punya kekuatan apa-apa secara struktural untuk merubah struktur yang ada di negara ini. Sehingga langkah untuk mempengaruhi dan merubah sistem paling tidak kelompok ini harus masuk ke dalam sistem tersebut.

Begitupun sebaliknya, HT di Indonesia juga tidak bisa dikatakan sebagai Organisasi Masyarakat Sipil (OMS), karena kriteria dalam OMS tidak terlihat dalam aktivitas dan perjuangan HTI. Kriteria organisasi yang dapat disebut sebagai OMS menurut Jamilah adalah: OMS memiliki potensi dalam mengembangkan sistem demokrasi diantaranya: Pertama, pola rekruitmen anggota secara terbuka dan mengedepankan prinsip persamaan dalam 
berorganisasi. Kedua, kelembagaan otonomi dengan kemampuan adaptasi, koherensi dan kompleksitas. Ketiga, memiliki sikaptoleransi, kepercayaan, dan kerjasam. Keempat, mengedepankan pluralisme di tengah kehidupan masyarakat yang bersifat heterogen. Kelima, OMS memiliki ciri 'density' atau dukungan rakyat yang luas sehingga kehadirannya menjadi wadah bagi masyarakat untuk mengaktualisasi dan mengartikulasikan diri mereka..

Berdasarkan kelima kriteria tersebut, maka HTI belum bisa dikategorikan sebagai OMS. Sementara Mohamed Nawab menyebutnya berbeda seperti yang di kemukan oleh Jamilah. Mohamed Nawab Mohamed Osman adalah seorang pemikir Islam yang konsen terhadap gerakan-gerakan Islam transnasional dan peneliti di S. Rajaratman School of International Studies, Nanyang Technological University, Singapura. Mohamed Nawab mengemukakan bahwa HTI adalah gerakan Islam semi-politik. Maksudnya, bahwa organisasi Islam ini memiliki tujuan ingin mendapatkan pengaruh dari massa yang besar demi tercapainya cita-cita perjuangan, tetapi keberadaan massa besar itu tidak terlalu penting untuk direkrut menjadi anggota HTI. Cukup sedikit saja orang-orang terpilih yang akan mempengaruhi mereka dengan pengetahuan Khilafah Islamiyah, nanti ketika datang massanya mereka akan mendukungnya.

Selain Mohamed Nawab, Haedar Nashir sebagaiPimpinan Pusat Muhammadiyah secara tidak langsung berpendapat hampir sama dengannya. Haedar Nashir mengkritik secara tajam dengan mengatakan bahwa gerakan HTI bukanlah tipologi yang mencirikan partai politik Islam, tetapi HTI adalah organisasi kemasyarakatan (ormas) biasa yang bergerak di bidang pendidikan, agama dan sosial. Jika aktivis-aktivis HTImenganggap dirinya sebagai partai politik, maka konsekuensi logisnya, ormas akan masuk dalam sistem demokrasi yang berlaku di Indonesia. Namun, sepertinya HTI memiliki pengertian tersendiri tentang partai politik dan demokasi.

Dalam hal kontestasi politik, HTI berkomitmen agar tidak terlibat dalampemilihan umumsebagaimana yang terjadi di Indonesia.Mereka justru menilai haram hukumnya untuk mengikuti pemilihan umum dalam sebuah negara yang masih menganut sistem demokrasi. Pernyataan semacam ini sering penulis dengar ketika berdiskusi dengan aktivis-aktivis HTI. Lebih lengkapnya mengenai pandangan mereka atas sistem demokrasi dapat ditelusuri dalam sebuah buku tulisan Abdul Qadir Zollum berjudul demokrasi sitem kufur.Ia termasuk salah seorang dedengkot HT paling aktif meneriakan sistem demokrasi sebagai sistem yang kufur sehingga haram bagi anggotanya untuk mengambil dan menerapkannya. 
Dalam politik, HTI memang terkesan bergerak setengah hati.Berpolitik tapi tidak mendirikan partai yang berjuang dalam kontestasi politik. Dengan kata lain, Mereka hanya mengkritik dan berusaha untuk merubah tatanan yang ada dalam sistem. Akan tetapi, mereka tidak mau terlibat dalam kontestasi dan perpolitikan yang ada di Indonesia, sehingga mereka tidak mampu memainkan peran-peran poltik atau fungsi-fungsi kepartaian, seperti partai-partai politik modern sekarang ini.

\section{Dakwah Hizbut Tahrir Melalui Sosial Media dan Publikasi}

Bentuk aktivitas dan dakwah yang dilakukan oleh pengurus dan kader HT, diantaranya yaitu publikasi melalui media. Agar aktivitas dan dakwah dapat mempengaruhi dan mengambil hati umat Islam, biasanya HTI mengikuti fikrah dan thariqah-nya. Media dan publikasi adalah salah satu sarana dakwah dan media sosialisasi sebagai bentuk pengejewantahan dari fikrah dan thariqah tersebut. Adapun bentuk media dan publikasi yang mereka lakukan antara lain sebagai berikut: Menerbitkan buku-buku sebagai rujukan dalam mengkaji dan mengadopsi pemikiran HT. Pendapat dan hukum serta pemikiran yang telah ditetapkan oleh HT sudah dihimpun dalam buku-buku baik yang dijadikan sebagai sumber materi pokok pembinaan ataupun sebagai materi pelengkap. Mereka menerjemahkan buku-buku HT dan pemikiran-pemikiran pimpinan HT seperti yang ditulis oleh Taqiyuddin An Nabhani maupun tulisan Abdul Qodir Dzolum. Penerbit-penerbit HTI terdiri dari Pustaka Thariqul Izzah dan Mahabbah Cipta Insani di Bogor Jawa Barat dan di Bangil Jawa Timur ada penerbit al-Izzah maupun HTI Press di Jakarta. Semua buku yang menjadi rujukan dalam halaqah dan pengajian HT telah diterbitkan dan dipublikasikan.

Beberapa buku yang telah diterjemahkan dan diterbitkan oleh beberapa penerbit milik ShababHT di Indonesia menjadi rujukan penting bagi anggotanya. antara lain:1. Peraturan Hidup dalam Islam(Nizham al-Islam).2. Sistem Pergaulan Pria-Wanita dalam Islam(An-Nizham al-Ijtima'i fi al-Islam). 3. Politik Partai: Strategi Partai Politik Islam(At-Takattul al-Hizbi). 4. Sistem Ekonomi Islam(An-Nizham alIqtishadi fi al-Islam). 5. Sistem Pemerintahan Islam(Nizham al-Hukm fi al-Islam). 6. Membentuk Kepribadian Islam(Asy-Syakhshiyyah al-Islamiyyah). 7. Dekonstruksi Khilafah: Skenario di Balik Runtuhnya Khilafah Islam(Kayfa Hudimat al-Khilafah). 8. Khilafah(Al-Khilafah).9. Sistem Peradilan Islam(Nizham al'Uqubat). 10. Panggilan untuk Umat Islam(Kitab Nida' Har). 11. Struktur Negara Khilafah: Pemerintahan dan Administrasi(Daulah Khilafah Islamiyah). 12. Pokok-pokok Pikiran Hizbut Tahrir(Mafahm Hizbut Tahrir).13. Pokok-pokok Pikiran Politik Hizbut Tahrir (Mafahim Siyasah li Hizbut Tahrir). 14. Daulah Islam(Ad-Dawlah al-Islamiyyah).15. 
Pengantar Undang-undang Negara Islam(Muqaddimah ad-Dustur). 16. Bunga Rampai Pemikiran Islam(Al-Fikr al-Islami). 17. Nalar Islam(At-Tafkir). 18. Hukumhukum Pembuktian dalam Pengadilan(Ahkam al-Bayyinat). 19. Beberapa Pandangan Politik menurut Hizbut Tahrir(Nadharat Siyasiyah li Hizbut Tahrir). 20. Kritik atas Sosialisme-Marxis(Naqd al-Isytirakiyyah al-Marksiyah). 21. Politik-Ekonomi Islam(AsSiyasah al-Iqtishadhiyyah al-Mutsla). 22. Mempercepat Proses Berpikir(Sur'ah alBadihah). 23. Kritik atas Teori Stipulasi dalam Undang-undang Barat(Naqd anNadhariyah al-Iltizami fi Qawanin al-Gharbiyyah). 24. Pilar-Pilar Nafsiyah Islamiyah(Min Muqowwimat an Nafsiyyah Al Islamiyyah).25. .Sistem Keuangan dalam Negara Khilafah(Al-Amwal fi Dawlah al-Khilafah).Selain dua puluh lima (25) buah kitab yang disebutkan di atas, masih banyak lagi kitab-kitab yang telah diterjemahkan oleh shabab HT untuk disebarluaskan di seluruh pelosok tanah air Indonesia.

Buku-buku di atas merupakan buku-buku (kitab-kitab) yang akan dijadikan sumber kajian bagi angota dan pengurus HTI. Buku-buku ini juga menjadi bacaan utama bagi anggota pemula (kader baru). Selain membaca ktab-kitab tersebut, mereka juga diwajibkan mengikutitsaqafah dengan carahalaqahrutin untuk mempelajari dan mendalami isi buku-buku tersebut. Ketidakhadiran dari setiaphalaqah tanpa alasan jelas bisa mengakibatkan teguran atau peringatan dari murabinya, dan bahkan pemecatan status keanggotaannya.Kajian kitab-kitabdalam halaqah selalu ditekankan Islamsebagai ajaran yang sempurna dan paripurna dan Islam sebagai ideologi partai yang superior dari ideologi lainnya. Tentunya ideologi Islam yang dimaksud adalah ideology yang merujuk kepada pandangan dedengkot HT sendiri. Karena pandangan HTI yang mengadopsi yang ketat terhadap karyakarya Taqiyuddin an-Nabhani, maka tidaklah berlebihan jika dikatakan bahwa ideologi HT sebenarnya adalah ideologi "an-Nabhanisme” (Rijal dalam Mufid (Ed), 2011: 45). Bahkan lebih jauh lagi, kelompok yang bergabung dalam organisasi HT oleh pengamat menyebutnya sebagai kelompok khilafist.

Khusus di Indonesia, sebagai langkah kongkrit untuk menjadikan media dan publikasi sebagai sarana dakwah, maka HTI telah memiliki toko buku sendiri yang mereka beri nama Khilafah Centre. Toko buku tersebut terbuka untuk umum dan menyediakan buku-buku dan referensi lain yang masih berkaitan dengan ideologi dan agenda politik HT.Dengan hadirnya Khilafah Centre, telah banyak memberikan kemudahan kepada masyarakat yang membutuhkan buku-buku yang berkaitan dengan bahan kajian yang gunakan oleh kader HT.

Publikasi HTI lainnya yaitu dengan menerbitkan majalah, tabloid dan bulletin. Majalah Al-Wa'ie“Media Politik \& Dakwah Al-Wa'ie Membangun Kesadaran Umat". merupakan majalah yang terbit sebulan sekali. Majalah ini 
Bergerak dengan Dua Sayap: Fenomena Gerakan Dakwah dan

Politik Hizbut Tahrir di Indonesia Pasca Reformasi

Aksa

biasanya mencetak 15.000 exemplar setiap edisi untuk disebarkan melalui agenagen yang ada berada diberbagai kota di Indonesia. HTI juga menerbitkan tabloid yang terbit dua kali setiap bulan dengan nama "Tabloid Media Umat Memperjuangkan Kehidupan Islam”. Tabloid Media Ummat mulai diterbitkan sejak tahun 2008 dengan ratusan agen yang tersebar dibeberapa kota-kota besar yang ada di Indonesia. Agen-agen yang tersebar di Pulau Jawa diantaranya terdapat di Kota-kota besar seperti Jakarta, Banten, Surabaya, Yogyakarta, Surakarta, Semarang, Demak, Madura. Juga di pulau Sumatera, Kalimantan, Sulawesi, Maluku, NTB bahkan sampai di Papua.

Sementara untuk agenda mingguan, HTI menerbitkan buletin yang diberi nama 'Al-Islam'. Awalnya, buletin ini diterbitkan dengan tidak memakai nama HTI, baru setelah tahun 2000 buletin ini resmi memakai nama Al-Islam dan dikeluarkan oleh Syabab Hizbut Tahrir. Sejak saat itulah buletin ini terbit satu kali dalam seminggu,Setiap terbit biasanya dicetak sebanyak 1.000.000 (1 juta) eksemplardan didistribusikan oleh para aktivis HTIterutama pada hari Jum'at di masjid-masjid yang ada di Kota-kota besar di Indonesia.Menurut K.H. Muhammad Al Khaththhath (salah seorang pimpinan DPP HTI) mengemukakan bahwa penerbitan buletin 'Al-Islam' memiliki dua maksud, pertama, Membangun kesadaran umat Islam agar kembali kepada Islam secara totalitas.Kedua, Mengajak umat untuk hidup berdamai dalam naungan daulah khilafah al- Islamiyyah. Judul dalam buletin merupakan respon mereka atas berbagai problem dan isu-isu yang sedang berkembang dan aktual. Dalam buletin al-Islam, tidak sedikit isinya selalu menggunakan bahasa provokasi terutama dalam membangkitkan semangat umat Islam. Sistem demokrasi terkadang diserang dengan pemikiran yang lebih sempit.

Bulletin "Al-Islam" yang memuat beberapa tema, baik tema politik, tema ekonomi, budaya maupun tema tentang dakwah dan jihad, seperti buletinyang terbit tahun 2004 diantaranya: Khilafah Solusi Problematika Umat Menyambut KHI, Hijrah menuju Khilafah Islamiyah, Konspirasi Kafir Barat Menyerang Umat Islam, Pemenuhan Kebutuhan Pokok, Tanggung Jawa siapa?, Fanastisme Kesukuan Awal Kehancuran Masyarakat, Umat Islam, Jihad, Bukan Kejahatan, kobarkan Jihad.Tema-tema tersebut hanyalah sedikit contoh dari ribuan opini yang sebarkan oleh aktivis HTI.Tema semacam ini sekaligus menunjukan konsentrasi dari kadernya dalam membangun wacana demi memperjuangkan tegaknya Khilafah alIslamiyyah.Selain itu, terdapat surat-surat terbuka kepada para penguasa dan pemimpin gerakan politik dan surat pernyataan yang dikeluarkan oleh Hizbut Tahrir dalam menanggapi berbagai isu-isu penting dari berbagai negara.

Selain publikasi dengan cara menerbitkan buku, tabloid, majalah dan buletin, HTI juga memanfaatkan media sosial sebagai sarana mendakwakan 
perjuangannya. Diantaranya mengoptimalkan pengelolaanwebsite, akun facebook, twitter dan You Tube. Sejak tahun 2004, HTI menggunakan website sebagai sebagai media untuk memposting berbagai bentuk kegiatan yang telah dilakukannya.

Media sosial yang digunakan selain website, akun facebook dimanfaatkan oleh HTI sebagai media sosialisasi. Dalam akun facebook yang dimiliki oleh HTI dengan alamat facebooknya 'Hizbut Tahrir Indonesia', fanpage ini telah disukai sebanyak 59.006 orang. Sementara facebook khusus anggota muslimahnya beralamat 'Muslimah Hizbut Tahrir Indonesia' dengan jumlah 47.875 orang yang telah memberikan tanda 'like'. Bukan saja komentar, berbagai bentuk kegiatan seperti demonstrasi, pertemuan dengan tokoh-tokoh Islam lainnyadi-upload melalui akun fanpage tersebut. Mereka juga sering meng-upload kegiatan seminar, dan diskusi dengan penjelasan singkatnya agar seluruh anggota dan simpatisan dari berbagai kota dapat melihat laporannya. Penting diketahui, bahwa akun facebook ini selain berfungsi sebagai media pelaporan hasil kegiatan, mereka juga memanfaatkannya untuk menggiring opini publik (Muthohirin, 2014: 153). Tulisan-tulisan singkat di facebook, oleh banyak pihak banyak yang memberikan berbagai tanggapan, respon dan komentar di dalamnya.

Selanjutnya twitter juga di gunakan untuk mensosialisasikan aktivitasnya. Akun twitter HTI yang berkantor pusat di Jakarta bisa masuk melalui alamat twitternya @di HizbuttahrirID untuk HTI dan @Women4Khilafah untuk MHTI. Pada saat penulis membuka akun twitternya, ada sebanyak 37.327 orang pengikut (followers) untuk twitter HTI dan 18.937 orang pengikut (followers) untuk twitter MHTI (Dikutip dari akun twitter resmi HTI dan MHTI pada hari rabu tanggal 23 Maret 2016 pukul 17.35 Wita). Dalam akun ini, kebanyakan dari mereka selalu aktif menanggapi berbagai persoalan yang hadapi oleh umat Islam dan persoalanpersoalan yang melanda bangsa ini. Mulai dari kekayaan alam yang tidak di kelola dengan baik sampai kepada carut-marutnya penegakkan hukum. Mereka juga mengungkapkan kebobrokan negara ini dengan sebagai akibat dari korupsi yang merajalela. Akun-akun media sosial HTI secara berkelanjutandikendalikanbidang infokom Pengurus PusatHTI . Jadi, dapat di maklumi jika isi status (status content) dua akun (facebook dan twitter) dalam menulis status terkait dengan aktivitas dan pergerakan politik Islam ini selalu baru dalam jeda beberapa jam. (Muthohirin, 2014: 154).

Dari sekian banyak kegiatan yang pernah dilakukan oleh HTI, sangat mudah kita temukan melalui rekaman-rekaman videonya di You Tube. Muktamar Khilafah atau Kongres Khilafah Internasional, Konferensi Rajab, Halaqah Islam dan Peradaban serta berbagai kegiatan seminar dan diskusi dapat kita saksikan melalui media ini. Sebagai contoh rekaman video di You Tube yang menampilkan 
Bergerak dengan Dua Sayap: Fenomena Gerakan Dakwah dan

Politik Hizbut Tahrir di Indonesia Pasca Reformasi

Aksa

Kegiatan Akbar seperti acara Kongres Internasional HTI. Kegiatan yang mereka unggah diikuti dengan berbagai komentar maupun pujian. Banyaknya peserta yang hadir di setiap acara tersebut, adalah merupakan salah satu keberhasilan dari kegiatan yang mereka lakukan.

\section{Simpulan}

Aktivitas dakwah HT menyadarkan akan penindasan dan keterbelakangan yang dialami umat Islam dengan menawarkan sistem khilafah sebagai solusi hidupnya. Kegiatan dakwah yang dilakukan HT di Indonesia pasca reformasisejatinya adalah kegiatan yang bersifat politik. Karena itu, HTI memainkan dua sayap dalam setiap aktivitas dan gerakannya yakni sayap dakwah dan sayap politik.Artinya semua aktivitas dakwah mempunyai unsur pilitik sebagai pijakan untuk berkuasa.Sebaliknya, kekuasaan yang diraih dari hasil intrik politik menjadi legitimasi dalam berdakwah.Aktivitas HT yang berorientasi dua sayap sangat ambiguitas, HT mengklaim dirinya sebagai organisasi politik tapi tidak mempunyai wadah dalam menyalurkan aspirasi politiknya.Selain itu, strategi politiknya terkesan bergerak setengah hati karena mereka tidak pernah ikut terlibat dalam kontestasi pemilu sebagaimana yang dilakukan oleh partai politik lainnya.Sementara dari sisi gerakan dakwah, narasi-narasi yang dikembangkannya sangat kental dengan ideologi tunggal (Khilafah Islamiyah) ala HT tetapi berlindung di balik negara Indonesia yang menganut ideologi Pancasila.

Media dan publikasi adalah salah satu sarana dakwah dan media sosialisasi sebagai bentuk pengejewantahan dari fikrah dan thariqahnya. HT telah menerbitkan kitab-kitab yang ditulis oleh Taqiyuddin An Nabhani maupun tulisan Abdul Qodir Dzolum sebagai rujukan dalam mengkaji dan mengadopsi pemikiran HT. Kitab Nizham al-Islam (Islam Struktural/Peraturan Hidup dalam Islam) adalah salah satu diantara kitab terpenting yang wajib dikaji dan dipedomani oleh anggotanya. HT di Indonesia telah memiliki penerbit mandiri yang konsen mempublikasikan dan menyebarkan pemikirannya, diantaranya adalah Penerbit Pustaka Thariqul Izzah dan Mahabbah Cipta Insani di Bogor Jawa Barat, Penerbit al-Izzah di Bangil Jawa Timur dan Penerbit HTI Press di Jakarta dan memiliki memiliki toko buku yang diberi nama Khilafah Centre. Selain menerbitkan buku-buku, mereka juga majalah, tabloid dan bulletin. Majalah "Media Politik \& Dakwah Al-Wa'ie Membangun Kesadaran Umat" biasanya dicetak 15.000 exemplar setiap edisi untuk disebarkan melalui agen-agen yang ada berada diberbagai kota di Indonesia. adapaun Tabloid "Media Umat Memperjuangkan Kehidupan Islam" terbit dua kali perbulan, dan bulletin 'Al-Islam' yang kelola oleh Syabab Hizbut Tahrir terbit sekali dalam seminggu. HTI juga memanfaatkan sosial media mengoptimalkan 
pengelolaanwebsite, akun facebook, twitter dan You Tube sebagai langkah kongkrit menjadikan sosial media dan publikasi sebagai sarana dakwah.

\section{Daftar Pustaka}

Hizbut Tahrir, Mengenal Hizbut Tahrir dan Strategi Dakwah Hizbut Tahrir. cet. III, Bogor: Thariqul Izzah, 2009.

Al Khaththath, Muhammad, Kata Pengantar dalamBundel Buletin Dakwah Al-Islam Melanjutkan Kehidupan Islam Tahun I. Bogor: Yasmin Press, 2004.

Cangara, Hafied, Komunikasi Politik, Teori dan Praktek, Jakarta: Rajawali Press, 2009.

DPP HTI Online, "Kaleidoskop Aktivitas Politik Dan Dakwah Hizbut Tahrir Indonesia", dalam Internet, http://www.hizbut-tahrir.or.id, diakses pada hari Kamis tanggal 24 Maret 2016 pukul 22.13. Wita.

Ismail al-Wahwah, "Dunia Membutuhkan Khilafah", dalam Buletin al-Wa'ie, VII, edisi 131 September 2007, hlm. 13.).

Jamilah, Siti, "Gerakan Hizbut Tahrir di Kota Pare-Pare: Membaca Pengaruh Pemikiran Taqiyuddin an-Nabhani”, Jurnal Diskursus Islam. Vol. 3. No.1, 2015.

Mufid, Ahmad Syafi'i (Ed), Perkembangan Paham Keagamaan Transnasional di Indonesia, Jakarta: Puslitbang dan Diklat Kemenag RI, 2011.

Muthohirin, Nafi'. 2014. Fundamentalisme Islam: Gerakan dan Tipologi Pemikiran Aktivis Dakwah Kampus. Jakarta: IndoStrategi.

Nashir, Haedar, Gerakan Islam Syari'at: Reproduksi Salafiyah Ideologis di Indonesia. Bandung: Mizan, 2013.

Naweb, M. O. Mohamed, "Reviving the chaliphatein the Nusantara: Hizbut Tahrir Indonesia's Mobilication Strategy and Its Impact in Indonesia", dalam Terorism and Political Violence (Routledge, 22: 4), 2010.

Rahmat, Immaduddin, Arus Baru Islam Radikal : Transmisi Revivalisme Islam Timur Tengah Ke Indonesia. Jakarta: Erlangga, 2005.

Rijal, Syamsul, Radikalisme Islam Klasik dan Kontemporer: Membanding Khawarij dan Hizbut Tahrir. Al-Fikr. Vol. 14. No. 2, 2010.

Subron, Sudarno, "Model Dakwah Hizbut Tahrir Indonesia" Profetika. Jurnal Studi Islam. Vol. 15, No. 1, 2014.

Wawancara dengan Didi Haryono (seorang aktivis HTI dengan umur 27 Tahun) pada tanggal 22 Februari 2016 di MesjidAl-Ikhlas Jln Traktor 2 No.2).

Zallom, Abdul Qadir,Demokrasi Sistem Kufur, terj M.Shidiq al-Jawi, Bogor: Pustaka Thariqul Izzah, 2009. 